\title{
Synthesis and biological evaluation of some new 2-oxazoline and salicylic acid derivatives
}

\author{
Evgenija Djurendić, ${ }^{a}$ Sanja Dojčinović Vujašković, ${ }^{a}$ Marija Sakač, ${ }^{a}$ Jovana Ajduković, a \\ Andrea Gaković, ${ }^{a *}$ Vesna Kojić, ${ }^{b}$ Gordana Bogdanović, ${ }^{b}$ Olivera Klisurić, ${ }^{c}$ and Katarina \\ Penov Gašía \\ ${ }^{a}$ Department of Chemistry, Faculty of Sciences, University of Novi Sad, Trg Dositeja Obradovića \\ 3, 21000 Novi Sad, Serbia \\ ${ }^{b}$ Oncology Institute of Vojvodina, Institutski put 4, 21204 Sremska Kamenica, Serbia \\ ${ }^{c}$ Department of Physics, Faculty of Sciences, University of Novi Sad, Trg Dositeja Obradovića 4, \\ 21000 Novi Sad, Serbia \\ E-mail: andrea.gakovic@dh.uns.ac.rs
}

\begin{abstract}
Starting from methyl salicylate and 2-amino-2-(hydroxymethyl)propane-1,3-diol 1a, or 2-amino2-methylpropane-1-ol $\mathbf{1 b}$, the 2-oxazoline derivatives $\mathbf{2 a}, \mathbf{2 b}$ or $\mathbf{3}$, as well as mono- $\mathbf{4 a}$ and $\mathbf{4 b}$ and bis- $\mathbf{5} \mathbf{a}$ and $\mathbf{5 b}$ derivatives of salicylic acid were synthesized. Reactions were performed by microwave irradiation in the presence of tetrabutylammonium bromide or metallic sodium as catalyst, as well as by conventional heating. Microwave-induced reaction of some diols, diamines and amino alcohols with methyl salicylate gave mono- and/or bis- derivatives of salicylic acid 4c, 5c, 5d, 6c, 8c, 7a, 7b, 8a and 8b. The mono- and bis-salicyloyl derivatives $4 \mathbf{c}$, 5c and 5d were transformed to the corresponding phenyl-azo derivatives $9,10 \mathbf{c}$ and 10d. The structure of compound $\mathbf{3}$ was proved by the X-ray analysis and the R-configuration on its stereocenter was confirmed. The antioxidant and cytotoxic activities of the synthesized derivatives were evaluated in a series of in vitro tests. Compounds $\mathbf{5 d}, \mathbf{8 b}$ and $\mathbf{8 c}$ exhibited very strong activity against hydroxyl radical. Six 4c, 5d, 8a-c, 10c of 16 tested compounds inhibited growth of MDA-MB-231 cells at a nanomolar concentration. Compounds 8c and 10c showed high cytotoxicity against MCF7 cells, whereas compounds 4c, 5d, 8a-c and 10d showed high activity against K562 cells.
\end{abstract}

Keywords: 2-Oxazoline derivatives, Salicylic acid derivatives, Microwave-assisted synthesis, Antioxidant activity, In vitro cytotoxicity, X-ray structural analysis 


\section{Introduction}

The complex sequence of cellular and molecular changes that take place during cancer formation are mediated by the different endogenous and exogenous stimuli. ${ }^{1}$ Among endogenous stimuli are intermediates of oxygen reduction, i.e. oxygen free radicals (OFR), or more generally, reactive oxygen species (ROS), which interact with DNA, forming various aducts. ${ }^{2 \mathrm{a}-\mathrm{c}}$ OFRs are important in the pathogenesis of many different diseases. ${ }^{2 a-d}$ ROS are also involved in the processes of aging. Because of that, the recent research activities have been directed to discovering new efficient antiradical and antioxidant compounds. Many phenol substances of plant origin or synthetic products and some salicylic acid derivatives as aspirin exhibit certain antioxidant and antiproliferative activities. ${ }^{3-14}$

Bearing the above in mind, one part of the present research was directed to the microwaveinduced synthesis of some new derivatives of salicylic acid, starting from different amino alcohols, diamines and diols, as well as to the determination of their antioxidant and antiproliferative activities. Microvawe irradiation is an alternative to conventional heating for introducing energy into reactions. One of the main advantages of microwave-assisted organic synthesis is the drastic decrease of reaction times. There is a considerable interest in the rapid synthesis of pharmacologically active compounds, such as 2-oxazolines. Namely, 2-oxazolines represent a very interesting class of heterocyclic compounds that is widely used in synthetic organic chemistry. There are numerous methods of forming 2-oxazoline ring, especially the microwave-assisted synthesis in which different amino alcohols, $\mathrm{N}$-( $\beta$-hydroxy) amides yielded differently substituted 2-oxazolines. ${ }^{15-17}$ Recently, it has been reported on the one-pot synthesis of 2-hydroxyphenyl-4-methyloxazoline-4-carboxamide substructures, found also in some natural cytotoxic agents such as brasilibactin A. ${ }^{18}$

Because of that, the other part of the present research was directed towards finding a suitable way for the microwave-catalyzed synthesis of some new 2-(2-hydroxyphenyl)-4-substituted derivatives of 2-oxazoline. Since the structures of these compounds are similar to those of some bioactive natural products such as the brasilibactin $\mathrm{A}$, it was interesting to investigate their antioxidant and cytotoxic activities against selected human cancer cell lines. ${ }^{19}$ Some azo-salicylic acids show biological activity and also azo derivatives of some phenols are useful precursors for the synthesis of anticarcinogenic, antiviral, antimicrobial and antimalaric agents. ${ }^{20}$ Hence, our research was also concerned with the synthesis of phenyl-azo-salicyloyl derivatives of diamines and amino alcohols and with testing of their biological activity.

\section{Results and discussion}

\section{Chemistry}

The 2-substituted oxazoline derivatives $\mathbf{2} \mathbf{a}^{21}, \mathbf{2} \mathbf{b}^{22}$ and $\mathbf{3}$ were synthesized starting from methyl salicylate and amino alcohols $\mathbf{1 a}$ or $\mathbf{1 b}$, using microwave irradiation under conditions described 
in the literature. ${ }^{23,24}$ Namely, microwave-assisted phase transfer catalyzed $\left(\mathrm{Bu}_{4} \mathrm{NBr}\right)$ reaction in basic medium $\left(\mathrm{K}_{2} \mathrm{CO}_{3}\right)$ of methyl salicylate with 2-amino-2-(hydroxymethyl)propane-1,3-diol 1a, at the mole ratio methyl salicylate/alcohol 1a $2: 1$ during $15 \mathrm{~min}$, yielded the oxazoline derivative 2a. However, when the mole ratio metyl salicylate/alcohol 1a was 6:1 and the reaction time extended to $30 \mathrm{~min}$, then, in addition to compound $\mathbf{2 a}$, the product was also salicyloyloxymethyl derivative $\mathbf{3}$ (Table 1, Table 2). 2-Amino-2-methylpropan-1-ol $\mathbf{1 b}$ gave the oxazoline derivative $\mathbf{2 b}$.

Table 1. Synthesized compounds from methyl salicylate and starting compounds 1a-1d and 6a-6

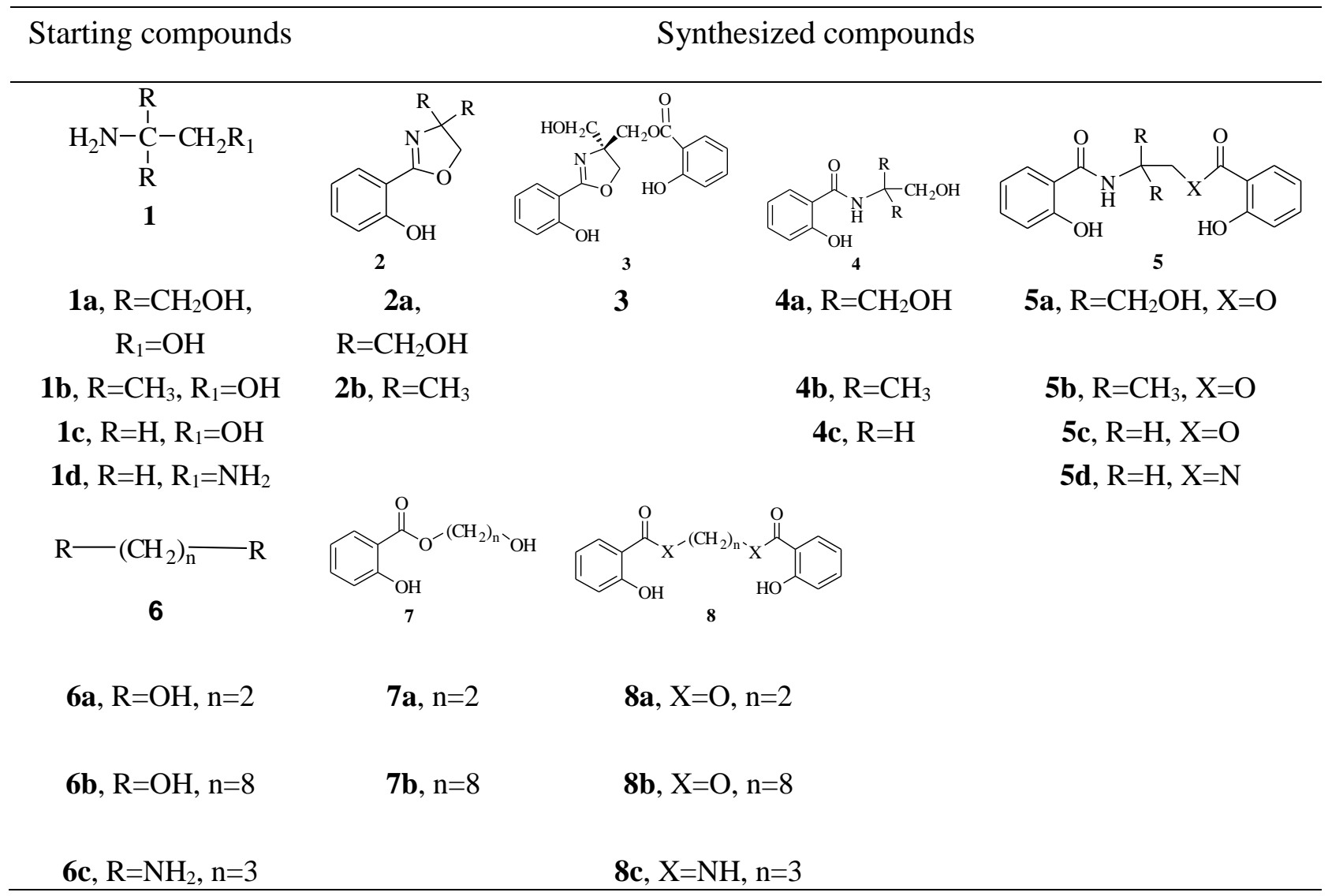

Table 2. Microwave-assisted synthesis catalyzed by $\mathrm{Bu}_{4} \mathrm{NBr}$ in basic conditions $\left(\mathrm{K}_{2} \mathrm{CO}_{3}\right)$

\begin{tabular}{cccccc}
\hline $\begin{array}{c}\text { Amino } \\
\text { alcohol }\end{array}$ & $\begin{array}{c}\text { Methyl salicylate/ } \\
\text { amino alcohol }\end{array}$ & $\begin{array}{c}\text { Time } \\
(\mathrm{min} .)\end{array}$ & $\begin{array}{c}\text { Temp. } \\
\left({ }^{\circ} \mathrm{C}\right)\end{array}$ & $\begin{array}{c}\text { MW power } \\
(\mathrm{W})\end{array}$ & $\begin{array}{c}\text { Products } \\
\text { (yield, \%) }\end{array}$ \\
\hline \multirow{2}{*}{$\mathbf{1 a}$} & $2: 1$ & 15 & 160 & 130 & $\mathbf{2 a}(42)$ \\
& $6: 1$ & 30 & 135 & 140 & $\mathbf{2 a}(18), \mathbf{3}(30)$ \\
\multirow{2}{*}{$\mathbf{1 b}$} & $2: 1$ & 15 & 160 & 160 & $\mathbf{2 b}(29)$ \\
& $4: 1$ & 15 & 160 & 160 & $\mathbf{2 b}(78)$ \\
\hline
\end{tabular}


When the microwave-assisted reaction of compounds $\mathbf{1 a}$ and $\mathbf{1 b}$ with methyl salicylate was carried out in the presence of sodium as catalyst, the products were also oxazolines $\mathbf{2 a}, \mathbf{2} \mathbf{b}$ and $\mathbf{3}$ (Table 3). Oxazolines $\mathbf{2 a}, \mathbf{2 b}$ and $\mathbf{3}$ were also formed at conventional heating of methyl salicylate and amino alcohol $\mathbf{1 a}$ and $\mathbf{1 b}$ in the presence of sodium as catalyst at $150{ }^{\circ} \mathrm{C}$ during $2 \mathrm{~h}$ (Table 3 ). However, under these reaction conditions, 2-amino-2-(hydroxymethyl)propane-1,3-diol 1a, apart from compounds $\mathbf{2 a}$ and $\mathbf{3}$, afforded also the mono $\mathbf{4} \mathbf{a}^{25}$ and bis $\mathbf{5 a}$ derivatives of salicylic acid, whereas 2-amino-2-methylpropane-1-ol $\mathbf{1 b}$, in addition to the oxazoline derivative $\mathbf{2} \mathbf{b}$, gave also the mono $\mathbf{4 b}$ and bis $\mathbf{5 b}$ derivatives of salicylic acid.

Table 3. Comparison of the results of the synthesis of salicylic acid derivatives obtained by conventional heating and microwave irradiation, in the presence of sodium as catalyst

\begin{tabular}{|c|c|c|}
\hline \multirow{3}{*}{$\begin{array}{c}\text { Starting } \\
\text { material } \\
\mathbf{1 a}\end{array}$} & \multicolumn{2}{|c|}{ Products (isolated yield, \%) } \\
\hline & Thermal heating $^{\mathrm{a}}$ & $\mathrm{MW}^{\mathrm{b}}$ \\
\hline & $\mathbf{2 a}(42), \mathbf{3}(6), \mathbf{4 a}(8), \mathbf{5 a}(1.3)$ & $\mathbf{2 a}(45), \mathbf{3}(6)$ \\
\hline $1 \mathbf{b}$ & $\mathbf{2 b}(16), \mathbf{4 b}(7), \mathbf{5 b}(17)$ & $\mathbf{2 b}(37)$ \\
\hline $1 c^{c}$ & $\mathbf{4 c}(38), \mathbf{5 c}(12)$ & $\mathbf{4 c}(65), 5 \mathbf{c}(7)$ \\
\hline $1 d^{\mathrm{c}}$ & $\mathbf{5 d}(23)$ & $\mathbf{5 d}(20)$ \\
\hline $\mathbf{6 a}$ & $\mathbf{8 a}(23)$ & $7 \mathbf{a}(16), \mathbf{8 a}(22)$ \\
\hline $\mathbf{6 b}$ & $\mathbf{8 b}(20)$ & $7 \mathbf{b}(11), \mathbf{8 b}(19)$ \\
\hline $6 c^{\mathrm{c}}$ & $8 \mathbf{c}(58)$ & $8 \mathbf{c}(35)$ \\
\hline
\end{tabular}

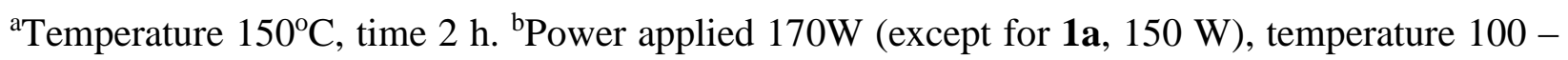
$160{ }^{\circ} \mathrm{C}$, time $15 \mathrm{~min}$ (except for $\mathbf{1 b}, 20 \mathrm{~min}$.). ${ }^{\mathrm{c}}$ The microwave-assisted synthesis was performed in the absence of sodium.

It can be supposed that the oxazoline derivatives $\mathbf{2} \mathbf{a}$ and $\mathbf{2} \mathbf{b}$ are formed by cyclization of the amides $\mathbf{4} \mathbf{a}^{25}$ and $\mathbf{4 b},{ }^{26}$ generated primarly in the reaction. Salicyloyl-oxazoline $\mathbf{3}$ is probably formed in a similar way from the salicyloyl-amide $\mathbf{5 a}$, or by transesterification of methyl salicylate with oxazoline $\mathbf{2 a}$. Cyclization of compounds $\mathbf{4 a}$ and $\mathbf{4 b}$ into a heterocyclic ring proceeds probably according to the mechanism presented in Scheme 1. 


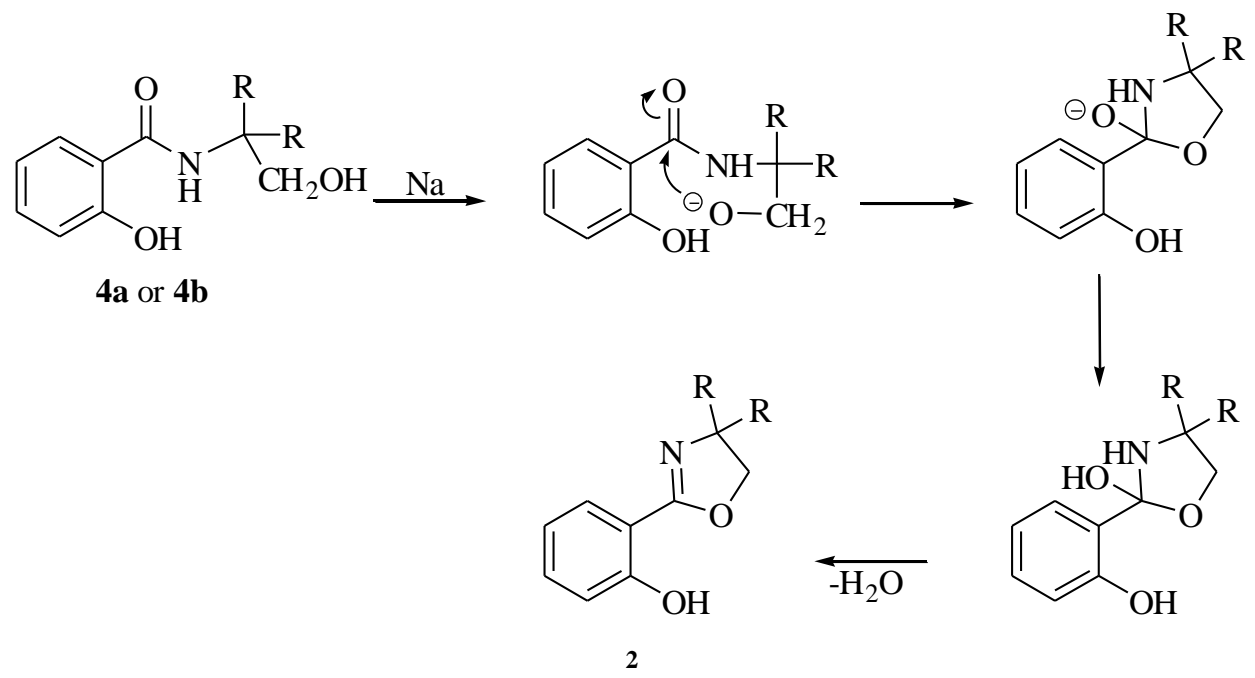

Scheme 1. Probable mechanism of cyclization of $\mathbf{4 a}$ and $\mathbf{4 b}$ to a heterocyclic ring.

Microwave-assisted reactions of 2-aminoethanol 1c, ethane-1,2-diamine 1d, ethane-1,2-diol 6a, octane-1,8- diol $\mathbf{6 b}$ and propane-1,3-diamine $\mathbf{6 c}$ with methyl salicylate were also carried out in present work; the microwave power, temperature, and reaction time being the same as above (Table 3). Under these conditions, amino alcohol 1c as well as diols $6 \mathbf{a}$ and $\mathbf{6 b}$ gave mono $4 \mathbf{c}$, $\mathbf{7 a},{ }^{27} \mathbf{7 b}$ and bis $\mathbf{5 c},{ }^{25} \mathbf{8 a},{ }^{28} \mathbf{8} \mathbf{b}^{29}$ derivatives of salicylic acid, whereas the diamines $\mathbf{1 d}$ and $\mathbf{6 c}$ gave only the respective bis derivatives $5 \mathbf{d}^{28}$ and $\mathbf{8} \mathbf{c}^{30}$.

In our previous works, compounds $4 \mathbf{c},{ }^{25} \mathbf{5 c},,^{25} \mathbf{5 d},{ }^{28}$ as well as $\mathbf{8 a - 8} \mathbf{c}^{28-30}$ were prepared from the corresponding starting substrates in the presence of sodium as catalyst by conventional heating at $150{ }^{\circ} \mathrm{C}$, for $2 \mathrm{~h}$, the corresponding yields are given in Table 3 . In the present work, at the same mole ratio of the reactants as in the above works ${ }^{25,28-30}$ the reaction time under microwave irradition was shortened to $15 \mathrm{~min}$ (Table 3). The microwave irradiation gave significantly higher yield of compound $\mathbf{4 c}$ compared to that obtained by conventional heating. The yield of compound $\mathbf{5 c}$ was somewhat lower, but the overall yield of $\mathbf{4 c}$ and $\mathbf{5 c}$ in the microwave-assisted reaction was significantly higher. It can be noticed that 2-aminoethanol 1c did not produce oxazoline derivative, either at conventional heating or microwave irradiation.

Coupling reactions of compunds $\mathbf{4 c}, \mathbf{5 c}$ and $\mathbf{5 d}$ with benzenediazonium chloride at $0{ }^{\circ} \mathrm{C}$ yielded azo derivatives $\mathbf{9}, \mathbf{1 0 c}$ and $\mathbf{1 0 d}$ (Scheme 2). 
<smiles>O=C(NCCO)c1cc(N=Nc2ccccc2)ccc1O</smiles>

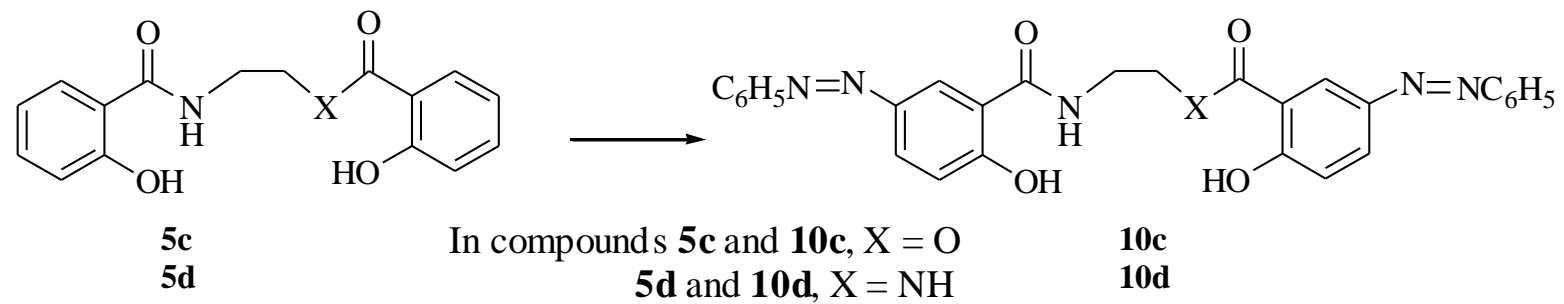

Scheme 2. Reagents and reaction conditions: benzenediazonium chloride solution, $10 \% \mathrm{NaOH}$, $0{ }^{\circ} \mathrm{C}, 30 \mathrm{~min}$.

Molecular and crystal structure of compound $\mathbf{3}$ was solved using X-ray structural analysis (Figure 1), ${ }^{31}$ showing the R-configuration at the stereocenter $(\mathrm{C} 4)$ of the molecule.

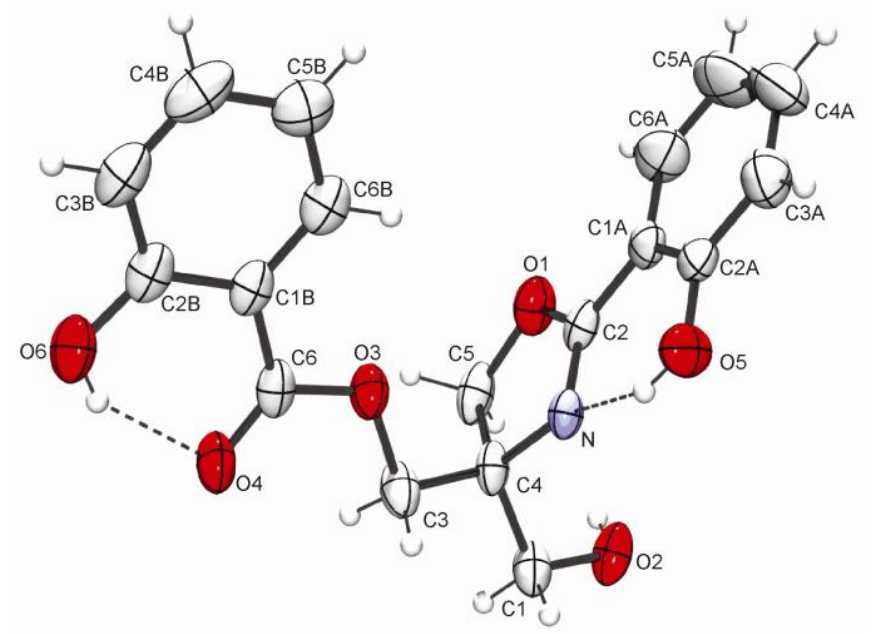

Figure 1. ORTEP presentation of structure 3 with the labeling of non-H atoms. Displacement ellipsoids are shown at the $50 \%$ probability level and $\mathrm{H}$ atoms are drawn as spheres of arbitrary radii. Intramolecular hydrogen bonds are shown as dashed lines.

As can be seen from Figure 1, the compound 3 contains intramolecular O-H...O and O-H... N hydrogen bonds. Crystal packing of compound $\mathbf{3}$ (Figure 2) shows that the molecules in the crystal are connected by the intermolecular $\mathrm{O}-\mathrm{H}$...O hydrogen bond along the c-axis. The hydrogen bond parameters are given in Table 4. 


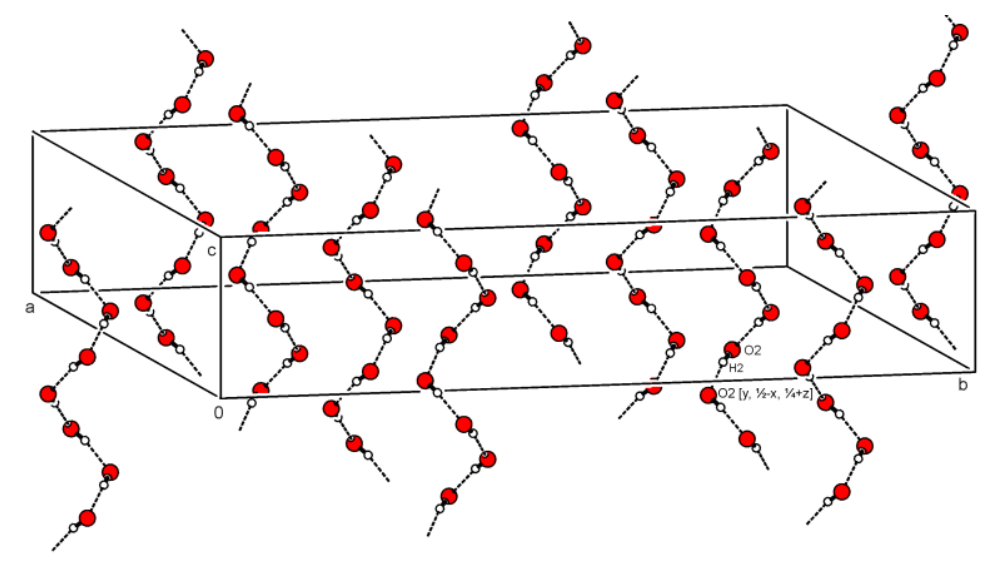

Figure 2. PLATON drawing showing the crystal packing of compound 3; Intermolecular hydrogen bond $\mathrm{O} 2-\mathrm{H} 2 \ldots \mathrm{O} 2$ is shown as dashed line (atoms that are not involved in $\mathrm{O} 2-\mathrm{H} 2 \ldots \mathrm{O} 2$ intermolecular hydrogen bond are not presented because of clarity).

Table 4. Intramolecular and intermolecular $\mathrm{O}-\mathrm{H} . . . \mathrm{O}$ hydrogen-bond parameters

\begin{tabular}{ccccc}
\hline D-H...A & D-H $(\AA)$ & H...A $(\AA)$ & D...A $(\AA)$ & D-H...A $\left({ }^{\circ}\right)$ \\
\hline O5-H5 ... & $0.85(3)$ & $1.82(3)$ & $2.588(3)$ & $150(3)$ \\
O6-H6 ..O4 & $0.81(3)$ & $1.87(3)$ & $2.609(2)$ & $152(3)$ \\
O2-H2 ..O2 $[\mathrm{y}, 1 / 2-\mathrm{x}, 1 / 4+\mathrm{z}]$ & $0.80(3)$ & $1.82(3)$ & $2.607(3)$ & $169(3)$ \\
\hline
\end{tabular}

\section{Biological properties}

Antioxidant activity. The antioxidant activities of the synthesized derivatives of salicylic acid were evaluated in a series of in vitro tests. In the DPPH (2,2-diphenyl-1-picrylhydrazyl) assay, the ability of tested compounds to act as donors of hydrogen atoms or electrons in transforming $\mathrm{DPPH} \bullet$ into its reduced form, DPPH-H, was measured by spectrophotometric method. ${ }^{32}$ All tested compounds were able to reduce the stable, purple-colored radical $\mathrm{DPPH} \bullet$ into yellowcolored DPPH-H form (Table 5). Commercial synthetic antioxidants, 3,5-di-tert-butyl-4hydroxytoluene (BHT) and 3-tert-butyl-4-hydroxyanisole (BHA) were used as positive controls. The strongest DPPH-scavenging activity showed the phenylazo derivatives 9 and 10c, which exhibited much stronger activity than their precursors $\mathbf{4 c}$ and $\mathbf{5 c}$, which indicates a positive influence of the introduced phenylazo groups. By comparing the activities of mono derivatives 4a and $\mathbf{4 c}$ with the corresponding bis derivatives $\mathbf{5 a}$ and $\mathbf{5 c}$ it can be seen that the latter are more active, indicating that the introduction of the new salicyloyl group increased the DPPHscavenging effect. This could be observed with oxazoline derivatives, too. Namely, by introducing the salicyloyl group into the oxazoline 2a, the more active salicyloyl oxazoline $\mathbf{3}$ is obtained. Also, it can be noted that the length of methylene chain in the esters 8a and $\mathbf{8 b}$ and amides 5d and 8c does not influence essentially the $\mathrm{IC}_{50}$ values. Commercial synthetic 
antioxidants BHT and BHA exhibited higher DPPH scavenging properties than those observed for the examined compounds.

Table 5. $\mathrm{IC}_{50}$ Values for radical scavenging activities of the tested compounds and commercial antioxidants BHA and BHT

\begin{tabular}{cccc}
\hline Comp. & $\begin{array}{c}\mathrm{DPPH} \\
\left(\mathrm{IC}_{50}, \mathrm{mM} / \mathrm{h}\right)\end{array}$ & $\begin{array}{c}\mathrm{HO}^{\bullet} \\
\left(\mathrm{IC}_{50}, \mathrm{mM}\right)\end{array}$ & $\begin{array}{c}\mathrm{LP} \\
\left(\mathrm{IC}_{50}, \mathrm{mM}\right)\end{array}$ \\
\hline $\mathbf{2 a}$ & 7.65 & 0.660 & $/$ \\
$\mathbf{2 b}$ & 3.20 & 1.98 & $/$ \\
$\mathbf{3}$ & 3.98 & 0.35 & $/$ \\
$\mathbf{4 a}$ & 6.52 & 4.400 & $/$ \\
$\mathbf{4 b}$ & 2.87 & 2.300 & 6.89 \\
$\mathbf{4 c}$ & 9.37 & 0.180 & $/$ \\
$\mathbf{5 a}$ & 2.40 & 0.920 & $/$ \\
$\mathbf{5 b}$ & 3.40 & 1.500 & 4.00 \\
$\mathbf{5 c}$ & 3.19 & 0.260 & $\mathrm{na}$ \\
$\mathbf{5 d}$ & 4.31 & 0.066 & 2.31 \\
$\mathbf{8 a}$ & 4.03 & 0.150 & $\mathrm{na}$ \\
$\mathbf{8 b}$ & 4.61 & 0.012 & 3.02 \\
$\mathbf{8 c}$ & 4.04 & 0.018 & 0.14 \\
$\mathbf{9}$ & 0.20 & 0.580 & 0.02 \\
$\mathbf{1 0 c}$ & 0.17 & 0.180 & 0.210 \\
$\mathbf{B H T}$ & 0.040 & 1.940 & 0.048 \\
$\mathbf{B H A}$ & 0.012 & 2.130 & \\
\hline
\end{tabular}

${ }^{\mathrm{a}} 50 \%$ inhibition not achieved.

The hydroxyl radical scavenging activity of the tested compounds (Table 5) was measured by the deoxyribose assay. ${ }^{32}$ Protective effect of the tested compounds was followed as their ability to remove hydroxyl radicals from the test solution and prevent the degradation. High inhibition of degradation was observed for all tested compounds, especially for compounds $\mathbf{8 c}, \mathbf{8 b}$ and $\mathbf{5 d}$. Comparison of the $\mathrm{IC}_{50}$ values for the tested compounds with the $\mathrm{IC}_{50}$ values for $\mathrm{BHT}$ and $\mathrm{BHA}$ indicates that salicylic acid derivatives are very strong scavengers of $\mathrm{OH}$ radicals (generated in Fenton`s reaction). It is evident that the activity is essentially influenced by the length of methylene chain in the ester and amide bis-derivatives. Namely, the bis-ester $\mathbf{8 b}$ and bis-amide 8c are more active than the corresponding compounds with smaller number of methylene groups, $\mathbf{8 a}$ and $\mathbf{5 d}$. Of the 2-oxazoline derivatives $\mathbf{2 a}, \mathbf{2 b}$ and $\mathbf{3}$ the most active is oxazoline $\mathbf{3}$, which has a salicyloyl group at $\mathrm{C}-4$ position.

The inhibition of lipid peroxidation (LP) was determined by measuring the formation of MDA, using liposomes as an oxidizable substrate. ${ }^{32}$ Some of the examined compounds showed 
notable inhibition of the $\mathrm{Fe}^{2+} /$ ascorbate induced LP in liposomes, compound 10c expressing the highest inhibition. Comparison of the $\mathrm{IC}_{50}$ values for tested compounds with the $\mathrm{IC}_{50}$ values for BHT and BHA shows that azo-derivatives 9 and 10c could be classified as promising inhibitors of LP.

\section{Cytotoxicity}

The synthesized compounds 2a, 2b, 3, 4a-c, 5a-d, 7a, 7b, 8a-c, 9, 10c, and 10d were evaluated for their in vitro cytotoxicity against MCF7, human breast adenocarcinoma ER+, MDA-MB-231, human breast adenocarcinoma ER-, PC3, prostate cancer, HeLa S3, cervix epithelioid carcinoma, Hs 294T, human melanoma, K562, chronic myelogenous leukemia, as well as MRC-5, normal fetal lung fibroblasts. Cytotoxic activity was determined by standard SRB assay, after exposure of cells to the tested compounds for $48 \mathrm{~h} .{ }^{33}$ The results are presented in Table 6.

Table 6. $\mathrm{IC}_{50}$ Values for in vitro cytotoxicity of the tested compounds and Dox

\begin{tabular}{cccccccc}
\hline Comp. & MCF7 & $\begin{array}{c}\text { MDA- } \\
\text { MB-231 }\end{array}$ & PC3 & HeLa S3 & Hs 294T & K562 & MRC-5 \\
\hline $\mathbf{2 a}$ & $>100$ & 43.66 & 19.43 & 60.04 & $>100$ & $>100$ & 88.06 \\
$\mathbf{2 b}$ & $>100$ & 2.37 & 8.78 & 4.67 & $>100$ & 34.44 & $>100$ \\
$\mathbf{3}$ & 41.01 & 20.32 & 13.45 & 1.06 & 30.04 & 56.36 & 98.31 \\
$\mathbf{4 a}$ & $>100$ & 10.37 & 11.96 & 43.01 & 74.05 & $>100$ & $>100$ \\
$\mathbf{4 b}$ & 2.25 & 40.94 & 40.04 & 13.71 & $>100$ & $>100$ & $>100$ \\
$\mathbf{4 c}$ & 1.46 & 0.06 & 19.09 & 0.04 & 0.59 & 0.38 & $>100$ \\
$\mathbf{5 a}$ & 22.25 & 56.31 & $>100$ & 40.58 & $>100$ & $>100$ & $>100$ \\
$\mathbf{5 b}$ & 10.85 & 0.53 & 13.45 & 9.87 & 19.43 & 30.85 & 78.62 \\
$\mathbf{5 c}$ & $>100$ & 9.77 & $>100$ & 0.05 & 24.58 & $>100$ & 99.48 \\
$\mathbf{5 d}$ & 0.12 & 0.01 & 0.20 & 9.87 & 0.28 & 0.29 & $>100$ \\
$\mathbf{7 a}$ & 16.12 & $>100$ & 12.12 & $/$ & $/$ & $/$ & $>100$ \\
$\mathbf{7 b}$ & 56.34 & $>100$ & 15.54 & $/$ & $/$ & $/$ & $>100$ \\
$\mathbf{8 a}$ & 2.28 & 0.0012 & $>100$ & 0.06 & 0.58 & 0.10 & $>100$ \\
$\mathbf{8 b}$ & 19.97 & 0.0004 & 19.97 & 4.67 & 23.33 & 0.55 & 86.99 \\
$\mathbf{8 c}$ & 0.08 & 0.03 & 0.08 & 0.21 & 0.04 & 0.83 & $>100$ \\
$\mathbf{9}$ & 3.02 & 12.29 & 0.55 & 2.06 & 2.24 & $>100$ & $>100$ \\
$\mathbf{1 0 c}$ & 0.02 & 0.04 & 0.02 & 1.42 & 0.45 & 5.66 & $>100$ \\
$\mathbf{1 0 d}$ & 0.17 & 0.10 & 0.06 & 0.36 & 0.44 & 0.45 & $>100$ \\
$\mathbf{D o x}$ & 0.75 & 0.12 & 95.61 & 1.17 & 15.39 & 0.36 & 0.12 \\
\hline & & & & & & &
\end{tabular}

It is important to point out that eight $4 \mathbf{c}, 5 \mathbf{c}, 5 \mathbf{d}, 8 \mathbf{a}-8 \mathbf{c}, 10 \mathbf{c}$ and $10 d$ out of eighteen tested compounds were active at nanomolar concentrations. Estrogen receptor negative MDA-MB-231 cells were most sensitive of all of the examined cell lines. Six $4 \mathbf{c}, \mathbf{5 d}, \mathbf{8 a - 8 c}, 10 \mathbf{c}$ out of sixteen 
tested compounds inhibited growth of MDA-MB-231 cells at nanomolar concentrations ( $\mathrm{IC}_{50}$ 0.0004-0.06 $\mu \mathrm{M}$ ).

The bis derivatives appeared to be very active antiproliferative agents. Thus, bis-salicyloyl derivative with eight methylene groups, $\mathbf{8 b}$, exhibited the most potent activity of all the tested compounds in the case of MDA-MB-231 cells. Its analog with two methylene groups, compound 8a, showed three times weaker activity against the mentioned cells, but still at the nanomolar level. Of the bis-amides $\mathbf{5 d}$ and $\mathbf{8 c}$ higher activity showed compound $\mathbf{8 c}$, having three methylene groups. The bis-derivatives with phenylazo groups, 10c and 10d, showed also strong cytotoxicity, especially against three cell lines: MCF7, MDA-MB-231 and PC3. By examining the differences of the following pairs of compounds $2 \mathbf{a}$ and $3,4 \mathbf{a}$ and $5 \mathbf{a}, \mathbf{4 b}$ and $\mathbf{5 b}, \mathbf{4} \mathbf{c}$ and $\mathbf{5 c}, 9$ and 10c, 7a and $\mathbf{8 a}$, as well as $7 \mathbf{b}$ and $\mathbf{8 b}$, it can be noticed that the introduction of salicyloyl or phenylazo-salicyloyl group into the corresponding starting compound changed significantly cytotoxicity against all of examined cell lines of human tumors. In the majority of cases, these groups increased the cytotoxicity of the synthesized compounds.

The established antitumor drug doxorubicin (Dox) was used as reference, and its activity was in the range of $\mathrm{IC}_{50}$ from 0.12 to $95.61 \mu \mathrm{M}$. The synthesized salicyloyl derivatives $\mathbf{4 c}, \mathbf{5 c}, \mathbf{5 d}, \mathbf{8 a}-$ 8c, 9, 10c and 10d were significantly more active against particular cell lines compared to Dox. A markedly higher cytotoxicity compared to Dox was observed with compounds 8a-8c. Namely, compound $\mathbf{8 a}$ was by 100 and compound $\mathbf{8 b}$ by 300 times more active against MDA-MB-231 cells than Dox. The most pronounced increase in the antiproliferative activity compared to Dox (i.e. by 385 times) showed compound 8c against Hs 294T cells. It should be noticed that compounds 5d, 8c, 9, 10c, and 10d exhibited strong cytotoxicity against PC3, in contrast to Dox, which was not practically toxic against these cells. Only compounds $\mathbf{2 a}, \mathbf{3}, \mathbf{5 b}, \mathbf{5 c}$, and $\mathbf{8 b}$ were slightly toxic to normal fetal lung fibroblasts cells, MRC-5, unlike doxorubicin which was very toxic.

By comparing the antioxidant and antiproliferative activities it can be concluded that bisester $\mathbf{8 b}$, which showed the highest activity as a scavenger of $\mathrm{OH}$ radicals ( $\mathrm{IC}_{50} 0.012 \mathrm{mM}$ ), exhibited also the highest antiproliferative activity (MDA-MB-231 cell lines, $\mathrm{IC}_{50} 0.0004 \mu \mathrm{M}$ ). Similarly, the most potent LP inhibitor, bis-azo derivative 10c ( $\mathrm{IC}_{50} 0.02 \mathrm{mM}$ ), showed cytotoxicity at a nanomolar concentration against three cell lines (MCF7, MDA-MB-231 and PC3).

It can be concluded that mono and bis derivatives of salicylic acid, with salicyloyl- and phenylazo-salicyloyl groups, as well as some new oxazoline derivatives, showed very potent cytotoxicity against K562, Hs 294T, HeLa S3, MCF7, PC3 and MDA-MB-231 cell lines, and strong antioxidant activity as scavengers of $\mathrm{OH}$ radicals and inhibitors of LP. 


\section{Experimental Section}

General. Melting points were determined using a Büchi SMP 20 apparatus and are uncorrected. The infrared spectra (wave numbers in $\mathrm{cm}^{-1}$ ) were taken on a Nexus 670 FT-IR spectrometer. Nuclear magnetic resonance (NMR) spectra were recorded on a Bruker AC 250 apparatus operating at $250 \mathrm{MHz}$ (proton) and $62.9 \mathrm{MHz}$ (carbon), using standard Bruker software, with tetramethylsilane as the internal standard. Chemical shifts are given in ppm ( $\delta$-scale); coupling constants $(J)$ are given in Hz. High resolution mass spectra (TOF) were recorded on a 6210 Time-of-Flight LC/MS Agilent Technologies (ESI+) instrument. GC/MS analyses were performed on an Agilent Technologies GC 7890A instrument with Mass Selective Detector 5975C. Absorbances of the reaction mixtures in free radical scavenging tests were recorded on a CECIL CE2021 spectrophotometer. The microwave reactor was a monomode system (Microwave Synthesis Sistem - Discover Bench Mate from CEM) with focused waves. Organic solutions were dried over $\mathrm{Na}_{2} \mathrm{SO}_{4}$ and evaporated on a rotary evaporator under reduced pressure. Column chromatography was performed on Merck grade 60 silica gel (0.063-0.2 mm).

\section{Chemical synthesis}

Compounds $4 \mathbf{c}, \mathbf{5 c}, \mathbf{5 d}, \mathbf{8 a}-\mathbf{c}$ were obtained in our previous studies ${ }^{25,28-30}$ by conventional heating of methyl salicylate with corresponding diols, diamines or amino alcohols, in the presence of sodium as a catalyst. Benzendiazonium chloride was prepared as described in literature. ${ }^{34}$

General procedure for the microwave-assisted reaction of amino alcohols $1 \mathrm{a}$ and $1 \mathrm{~b}$ with methyl salicylate, catalyzed by $\mathrm{Bu}_{4} \mathrm{NBr}$, to obtain compounds $(\mathbf{2 a})^{21},(2 \mathrm{~b})^{22}$ and (3)

Amino alcohols 1a and 1b $(5 \mathrm{mmol})$, methyl salicylate $(10 \mathrm{mmol}$ and $30 \mathrm{mmol}$ for $\mathbf{1 a}$ and 20 mmol for $1 \mathbf{b}), \mathrm{K}_{2} \mathrm{CO}_{3}(10 \mathrm{mmol}), \mathrm{Bu} 4 \mathrm{NBr}(0.2 \mathrm{mmol})$ and $\mathrm{DMF}(2 \mathrm{~mL})$ were mixed and exposed to microwave irradiation under the indicated conditions (see Table 2). After cooling, the reaction mixture was poured into water, $1 \mathrm{M} \mathrm{NaOH}$ was added to $\mathrm{pH}$ 9, and extracted with $\mathrm{CH}_{2} \mathrm{Cl}_{2}$. The organic extracts were dried and evaporated to dryness. Purification by column chromatography (30 g silica gel, toluene - EtOAc, 9:1 for $\mathbf{3}$ then 2:1 for $\mathbf{2 a}$, 20:1 for $\mathbf{2 b}$ ), afforded the corresponding products in yields given in Table 2 .

(R)-4-Hydroxymethyl-2-(2-hydroxyphenyl)-4-salicyloyloxymethyl-4,5-dihydro- oxazole (3). Colorless crystals ( $\mathrm{mp} 85^{\circ} \mathrm{C}$ after recrystallization from chloroform $-n$-hexane). $\mathrm{IR}(\mathrm{KBr}): 3426$ (br), 3194 (br), 1682 (vs), 1641 (vs), 1615 (vs), 1586 (s), 1486 (vs), 1402 (s), 1370 (s), 1298 (s), 1257 (s), 1210 (m), 1161 (s), 1071 (s), 769 (s), 749 (s), 700 (m). ${ }^{1} \mathrm{H}$ NMR (DMSO-D6): 3.64 (bs, $2 \mathrm{H}, \mathrm{CH}_{2} \mathrm{OH}$ ); 4.32-4.54 (m, 4H, $\mathrm{CH}_{2} \mathrm{O}_{2} \mathrm{C}$ and C-5); 5.40 (bs, $\left.1 \mathrm{H}, \mathrm{OH}\right) ; 6.72-7.60$ (m, 8H, H-Ar); 10.38 (bs, 1H, HO-Ar); 12.92 (bs, 1H, HO-Ar). ${ }^{13} \mathrm{C}$ NMR (DMSO-D6): $63.87\left(\mathrm{CH}_{2} \mathrm{OH}\right.$ ); 66.95 $\left(\mathrm{CH}_{2} \mathrm{O}_{2} \mathrm{C}\right) ; 71.05$ (C-4); 74.50 (C-5); 110.26 (C-1, Ar); 113.17 (C-1', Ar); 116.81 (C-3, Ar); 117.76 (C-3', Ar); 119.36 (C-5, Ar); 119.73 (C-5', Ar); 128.18 (C-6, Ar); 130.09 (C-6', Ar); 134.30 (C-4, Ar); 136.15 (C-4', Ar); 159.48 (C-2, Ar); 160.36 (C-2', Ar); 165.83 (C-2); 168.66 $\left(\mathrm{C}=\mathrm{O}\right.$ ). HRMS (TOF) $m / z: \mathrm{C}_{18} \mathrm{H}_{17} \mathrm{NO}_{6}[\mathrm{M}+\mathrm{H}]^{+}$calculated: 343.11286, found: 344.11403 . 
General procedure for the microwave-assisted reaction of amino alcohols 1a or $1 \mathrm{~b}$ or diols 6a or $6 \mathrm{~b}$ with methyl salicylate, catalyzed by $\mathrm{Na}$, to obtain compounds $\left(2 \mathrm{a},{ }^{21} 2 \mathrm{~b},{ }^{22} 3,7 \mathrm{a},{ }^{27}\right.$ $7 \mathrm{~b}, 8 \mathrm{a}^{28} \mathbf{8 b}^{29)}$

Amino alcohols $1 \mathbf{a}$ or $\mathbf{1 b}(4 \mathrm{mmol})$, or diols $\mathbf{6 a}$ or $\mathbf{6 b}(12 \mathrm{mmol})$, methyl salicylate $(24 \mathrm{mmol})$ and metallic $\mathrm{Na}(1 \mathrm{mmol})$ were heated at $110{ }^{\circ} \mathrm{C}$ for $10 \mathrm{~min}$. The reaction mixture was cooled to room temperature, transfered to the microwave reactor and the reaction performed under conditions given in Table 3. Then, the reaction mixture was diluted with water, $1 \mathrm{M} \mathrm{NaOH}$ was added to $\mathrm{pH} 9$, and extracted with $\mathrm{CH}_{2} \mathrm{Cl}_{2}$. The combined extracts were dried, evaporated to dryness, and the crude product was purified by column chromatography (toluene - EtOAc, $9: 1$ for $\mathbf{3}$, then 2:1 for $\mathbf{2 a}$ or toluene - EtOAc, $20: 1$ for $\mathbf{2 b}$ or petrol ether - acetone $12: 1$ for $\mathbf{7 a}$ and $\mathbf{8 a}$, i.e. $\mathbf{7 b}$ and $\mathbf{8 b}$ ). The yields of obtained products are given in Table 3.

8-Hydroxyoctyl salicylate (7b). Colorless oil. IR (film): 3341 (br), 1674 (vs), 1614 (vs), 1586 (s), 1486 (s), 1396 (m), 1302 (s), 1251 (s), 1215 (s), 1158 (s), 1090 (s), 758 (s), 701 (s). ${ }^{1} \mathrm{H}$ NMR $\left(\mathrm{CDCl}_{3}\right): 1.23-1.79\left(\mathrm{~m}, 12 \mathrm{H}, 6 \mathrm{CH}_{2}\right) ; 2.44(\mathrm{bs}, 1 \mathrm{H}, \mathrm{OH}) ; 3.58\left(\mathrm{t}, 2 \mathrm{H}, \mathrm{CH}_{2} \mathrm{OH}, J=6.5 \mathrm{~Hz}\right)$; $4.29\left(\mathrm{t}, 2 \mathrm{H}, \mathrm{CO}_{2} \mathrm{CH}_{2}, J=6.5 \mathrm{~Hz}\right) ; 6.81-7.83(\mathrm{~m}, 4 \mathrm{H}, \mathrm{H}-\mathrm{Ar}) ; 10.85$ (s, 1H, HO-Ar). ${ }^{13} \mathrm{C} \mathrm{NMR}$ $\left(\mathrm{CDCl}_{3}\right): 25.44,25.63,28.24,28.94,29.04$ and $32.38\left(6 \mathrm{CH}_{2}\right) ; 62.35\left(\mathrm{CH}_{2} \mathrm{OH}\right) ; 65.21\left(\mathrm{CO}_{2} \mathrm{CH}_{2}\right)$; 112.31 (C-1); 117.23 (C-3); 118.85 (C-5); 129.59 (C-6); 135.31 (C-4); 161.30 (C-2); 169.96 (C=O). HRMS (TOF) $m / z: \mathrm{C}_{15} \mathrm{H}_{22} \mathrm{O}_{4}[\mathrm{M}+\mathrm{H}]^{+}$calculated: 267.15909, found: 267.16005; [M+Na $]^{+}$ calculated: 289.14103 , found: 289.14086.

General procedure for the microwave-assisted reaction of amino alcohol 1c or diamines 1d and $6 \mathrm{c}$ with methyl salicylate, without catalyst, to obtain compounds $\left(4 \mathrm{c},{ }^{25} 5 \mathrm{c},{ }^{25} 5 \mathrm{~d},{ }^{28} 8 \mathrm{c}^{30}\right)$ The corresponding amine $(10 \mathrm{mmol})$ was added carefully to methyl salicylate $(20 \mathrm{mmol})$ cooled to $0-5{ }^{\circ} \mathrm{C}$, and the reaction mixture was left at the same temperature for $30 \mathrm{~min}$. Then, the mixture was irradiated with microwaves under the conditions given in Table 3. The reaction mixture was diluted with water, $1 \mathrm{M} \mathrm{NaOH}$ was added to $\mathrm{pH} 8$, and then extracted with $\mathrm{CH}_{2} \mathrm{Cl}_{2}$ and EtOAc. The joint extracts were dried and the solvent removed. The obtained crude mixture was separated on silica gel column (toluene, then toluene - EtOAc 4:1). The resulting products were $4 \mathbf{c}\left(\mathrm{mp} 117^{\circ} \mathrm{C}\right.$ after recrystallization from chloroform, mp $\left.117^{\circ} \mathrm{C}{ }^{23}\right), 5 \mathbf{c}\left(\mathrm{mp} 97{ }^{\circ} \mathrm{C}\right.$ after recrystallization from $\mathrm{CH}_{2} \mathrm{Cl}_{2}-n$-hexane, lit ${ }^{23} \mathrm{mp} 98^{\circ} \mathrm{C}$ ), $\mathbf{5 d}\left(\mathrm{mp} 184{ }^{\circ} \mathrm{C}\right.$ after recrystallization from $95 \%$ ethanol, mp $\left.185{ }^{\circ} \mathrm{C}{ }^{24}\right)$, and $8 \mathrm{c}\left(\mathrm{mp} 183{ }^{\circ} \mathrm{C}\right.$ after recrystallization from $95 \%$ ethanol, $\left.\mathrm{mp} 184-185^{\circ} \mathrm{C}^{26}\right)$ in yields given in Table 3.

General procedure for conventional synthesis catalyzed by metallic sodium, to obtain compounds (2a, 2b, 3, 4a, $\left.{ }^{25} \mathbf{4 b},{ }^{26} 5 \mathbf{a}, 5 \mathbf{b}\right)$

Methyl salicylate $(10 \mathrm{mmol})$, amino alcohols $1 \mathbf{a}$ or $\mathbf{1 b}(4 \mathrm{mmol})$ and metallic $\mathrm{Na}(1 \mathrm{~mol})$ were boiled at $150^{\circ} \mathrm{C}$ for $2 \mathrm{~h}$. The reaction mixture was diluted with water, $\mathrm{HCl}(1: 1)$ was added to $\mathrm{pH}$ 7, and extracted with EtOAc. The joint extracts were dried and the desiccant and solvent were removed. The product mixture was separated on silica gel column [toluene, then toluene EtOAc, 9 : 1 for $\mathbf{2 a}, \mathbf{3}, \mathbf{4 a}\left(\mathrm{mp} 122-123{ }^{\circ} \mathrm{C}\right.$ after recrystallization from EtOAc, mp 122-123 ${ }^{\circ} \mathrm{C}^{23}$ ) 
and 5a; toluene, then toluene - EtOAc, $20: 1$ for $\mathbf{2 b}$ and $\mathbf{5 b}$, then EtOAc for $\mathbf{4 b}$ ]; the yields are given in Table 3.

3-Hydroxy-2-(2-hydroxybenzamido)-2-(hydroxymethyl)propyl-2-hydroxybenzoate (5a). Yellow oil. IR (film): 3335 (br), 1681 (vs), 1640 (vs), 1614 (vs), 1539 (vs), 1487 (vs), 1455 (m), 1365 (m), 1302 (m), 1248 (m), 1214 (m), 1159 (s), 755 (s), 700 (s). ${ }^{1} \mathrm{H}$ NMR (acetone-D6): 3.97 (bs, $\left.4 \mathrm{H}, 2 \mathrm{CH}_{2} \mathrm{OH}\right) ; 4.77$ (s, 2H, $\mathrm{CH}_{2} \mathrm{O}_{2} \mathrm{C}$ ); 6.84-7.89 (m, 8H, H-Ar); 10.66 (bs, $\left.1 \mathrm{H}, \mathrm{HO}-\mathrm{Ar}\right) .{ }^{13} \mathrm{C}$ NMR (acetone-D6): 62.17 and $64.46\left(2 \mathrm{CH}_{2} \mathrm{OH}\right) ; 65.31\left(\mathrm{CH}_{2} \mathrm{O}_{2} \mathrm{C}\right) ; 71.17(\mathrm{~N}-\mathrm{Cq}) ; 113.24(\mathrm{C}-1$, Ar); 116.61 (C-1', Ar); 118.16 (C-3, Ar); 118.45 (C-3', Ar); 119.57 (C-5, Ar); 120.12 (C-5', Ar); 128.71 (C-6, Ar); 130.93 (C-6', Ar); 134.74 (C-4, Ar); 136.74 (C-4', Ar); 161.28 (C-2, Ar); 162.31 (C-2', Ar); 170.57 (C=O, amide); 171.03 (C=O, ester). HRMS (TOF) m/z: $\mathrm{C}_{18} \mathrm{H}_{19} \mathrm{NO}_{7}$ [M+H-H $\left.\mathrm{H}_{2} \mathrm{O}\right]^{+}$calculated: 344.11286 , found: 344.11253; $[\mathrm{M}+\mathrm{H}]^{+}$calculated: 362.12343 , found: 362.12358; $[\mathrm{M}+\mathrm{Na}]^{+}$calculated: 384.10537 , found: 384.10550 .

2(2-Hydroxybenzamido)-2-methylpropyl-2-hydroxybenzoate (5b). Yellowish oil. IR (film): 3385 (br), 1676 (s), 1643 (s), 1614 (s), 1537 (s), 1488 (s), 1455 (sh), 1376 (m), 1302 (m), 1249 (m), 1212 (m), 1159 (m), 750 (s), 698 (s). ${ }^{1} \mathrm{H} \mathrm{NMR}\left(\mathrm{CDCl}_{3}\right): 1.59$ (s, 6H, 2CH$) ; 4.59$ (s, 2H, $\mathrm{CH}_{2} \mathrm{O}_{2} \mathrm{C}$ ); 6.57 (s, 1H, CONH); 6.80-7.83 (m, 8H, H-Ar); 10.64 (s, 1H, HO-Ar); 12.29 (s, 1H, HO-Ar). ${ }^{13} \mathrm{C} \mathrm{NMR}\left(\mathrm{CDCl}_{3}\right): 24.03\left(2 \mathrm{CH}_{3}\right) ; 54.51(\mathrm{~N}-\mathrm{Cq}) ; 69.93\left(\mathrm{CH}_{2} \mathrm{O}_{2} \mathrm{C}\right) ; 112.14(\mathrm{C}-1, \mathrm{Ar})$; 114.64 (C-1', Ar); 117.81 (C-3, Ar); 118.66 (C-3', Ar); 118.73 (C-5, Ar); 119.36 (C-5', Ar); 125.36 (C-6, Ar); 129.69 (C-6', Ar); 134.18 (C-4, Ar); 136.19 (C-4', Ar); 161.67 (C-2, Ar); 161.81 (C-2', Ar); 170.21 (C=O, amide); 170.28 (C=O, ester). HRMS (TOF) $m / z: \mathrm{C}_{18} \mathrm{H}_{19} \mathrm{NO}_{5}$ [M-H] calculated: 328.11905, found: 328.11815 .

\section{General procedure for preparation of azo-derivatives $(9,10 \mathrm{c}$ and $10 \mathrm{~d})$}

To $\mathrm{NaOH}$ solution (10\%; $10 \mathrm{mmol}$ for $\mathbf{4 c} ; 20 \mathrm{mmol}$ for $\mathbf{5 c}$ and $\mathbf{5 d}$ ) the compounds $\mathbf{4 c}, \mathbf{5 c}$ or $\mathbf{5 d}$ ( $5 \mathrm{mmol}$ ) were added and the solution was cooled to $0-5{ }^{\circ} \mathrm{C}$. After that the cold freshly prepared benzenediazonium chloride solution ${ }^{31}(5 \mathrm{~mL}$ for $\mathbf{4 c}, 12.5 \mathrm{~mL}$ for $\mathbf{5 c}$ and $\mathbf{5 d}$ ) was added very slowly (the $\mathrm{pH} 8-9$ ). When all the diazonium salt solution was added, the mixture was left in an ice bath with stirring for $30 \mathrm{~min}$. After that, distilled water and $\mathrm{HCl}(1: 1$ to make the $\mathrm{pH}$ 56) were added, and the content was stirred at the same temperature for $1 \mathrm{~h}$. After the reaction was finished, the reaction mixture was filtered and crude products were recrystallyzed to obtained pure compounds $9,10 \mathrm{c}$ or $10 \mathrm{~d}$.

2-Hydroxy-N-(2-hydroxyethyl)-5-phenylazobenzamide (9). Orange crystals (81\%, mp 152$153{ }^{\circ} \mathrm{C}$ after recrystallization from acetone $-n$-hexane). IR (KBr): 3407 (br), 1641 (vs), 1590 (vs), 1549 (vs), 1496 (vs), 1378 (m), 1358 (s), 1251 (m), 1060 (s), 836 (m), 802 (m), 764 (m), 685 (m). ${ }^{1} \mathrm{H}$ NMR (acetone-D6): 3.59-3.62 (m, 2H, H-1'`); 3.74 (t, 2H, H-2', J = $6.7 \mathrm{~Hz}$ ); 4.24 (bs, 1H, OH); 7.07 (d, 1H, H-3, J = 8.9 Hz); 7.44-7.92 (m, 5H, H-Ar); 8.01 (dd, 1H, H-4, J3,4 = $\left.8.9 \mathrm{~Hz}, J_{4,6}=2.2 \mathrm{~Hz}\right) ; 8.48\left(\mathrm{~d}, 1 \mathrm{H}, \mathrm{H}-6, J_{6,4}=2.2 \mathrm{~Hz}\right) ; 8.65(\mathrm{bs}, 1 \mathrm{H}, \mathrm{NH}) .{ }^{13} \mathrm{C}$ NMR (acetoneD6): 43.14 (C-1'); 61.00 (C-2'); 115.48 (C-1, Ar); 119.55 (C-3, Ar); 123.17, 130.02 and 131.53 $(\mathrm{CH}$ from $\mathrm{PhN}=\mathrm{N}) ; 125.26(\mathrm{C}-6, \mathrm{Ar}) ; 127.06$ (C-4, Ar); 145.60 and 153.29 (C-5, Ar and Cq from 
$\mathrm{PhN}=\mathrm{N}) ; 165.32$ (C-2, Ar); 170.79 (C=O, amide). HRMS (TOF) m/z: $\mathrm{C}_{15} \mathrm{H}_{15} \mathrm{~N}_{3} \mathrm{O}_{3}[\mathrm{M}+\mathrm{H}]^{+}$ calculated: 286.11862, found: 286.11959; [M+Na $]^{+}$calculated: 308.10056 , found: 308.10048 .

5,5'-Bis(phenylazo)-2-(2-hydroxybenzamido)ethyl-2-hydroxybenzoate (10c). Orange crystals (65\%, mp 223-224 ${ }^{\circ} \mathrm{C}$ after recrystallization from acetone). IR (KBr): 3422 (br), 1674 (s), 1644 (vs), 1589 (vs), 1540 (vs), 1492 (vs), 1412 (s), 1372 (m), 1288 (m), 1207 (m), 1075 (s), 836 (s), 794 (s), 765 (m), 686 (m). ${ }^{1} \mathrm{H}$ NMR (DMSO-D6): 3.89 (t, 2H, $\left.\mathrm{CONHCH}_{2}, J=6.7 \mathrm{~Hz}\right) ; 4.52$ (t, $\left.2 \mathrm{H}, \mathrm{COOCH}_{2}, J=6.7 \mathrm{~Hz}\right) ; 6.88(\mathrm{~d}, 1 \mathrm{H}, \mathrm{H}-3, \mathrm{Ar}, J=9.0 \mathrm{~Hz}) ; 7.15$ (d, 1H, H-3', Ar, J= 8.9 Hz); 7.39-7.86 (m, 10H, from $\mathrm{PhN}=\mathrm{N}) ; 7.99\left(\mathrm{dd}, 1 \mathrm{H}, \mathrm{H}-4, \mathrm{Ar}, J_{3,4}=9.0 \mathrm{~Hz}, J_{4,6}=2.6 \mathrm{~Hz}\right.$ ); 8.03 (dd, $\left.1 \mathrm{H}, \mathrm{H}-4^{\prime}, \mathrm{Ar}, J_{3^{\prime}, 4^{\prime}}=8.9 \mathrm{~Hz}, J_{4^{\prime}, 6^{\prime}}=2.5 \mathrm{~Hz}\right) ; 8.36$ (d, 1H, H-6', Ar, J=2.5 Hz); 8.48 (d, 1H, H-6, $\mathrm{Ar}, J=2.6 \mathrm{~Hz}) ; 10.09$ (bs, 1H, NH). ${ }^{13} \mathrm{C}$ NMR (DMSO-D6): $37.91\left(\mathrm{CH}_{2} \mathrm{NH}\right) ; 64.28\left(\mathrm{COOCH}_{2}\right)$; 114.40 (C-1, Ar); 116.80 (C-1', Ar); 118.78 (C-3, Ar); 120.01 (C-3', Ar); 121.93, 121.39, 129.36 (6CH from 2PhN=N); 125.52 (C-4, Ar); 126.89 (C-4', Ar); 128.02 (C-6, Ar); 129.36 (C-6', Ar); $127.17 ; 129.29 ; 131.05 ; 142.56 ; 144.41 ; 151.83 ; 152.29 ; 162.55 ; 167.07 ; 167.69 ; 168.38$ $(2 \mathrm{C}=\mathrm{O})$. HRMS (TOF) m/z: $\mathrm{C}_{28} \mathrm{H}_{23} \mathrm{~N}_{5} \mathrm{O}_{5}[\mathrm{M}+\mathrm{H}]^{+}$calculated: 510.17720, found: 510.17674 .

5,5'-Bis(phenylazo)ethane-1,2-diyl-bis(2-hydroxybenzamide) (10d). Yellow crystals (50\%, $\mathrm{mp}>310{ }^{\circ} \mathrm{C}$ after recrystallization from dioxane). IR (KBr): 3443 (br), 1650 (vs), 1598 (vs), 1550 (vs), 1505 (vs), 1394 (s), 1304 (s), 1262 (s), 1207 (s), 841 (s), 785 (s), 698 (s). ${ }^{1} \mathrm{H} \mathrm{NMR}$ (DMSO-D6): 3.54 (t, 4H, 2CONHCH $2, J=6.7 \mathrm{~Hz}$ ); 7.08 (d, 2H, H-3 and H-3', Ar, $J=9.0 \mathrm{~Hz}$ ); 7.48-7.84 (m, $10 \mathrm{H}$, from $2 \mathrm{PhN}=\mathrm{N}) ; 7.84\left(\mathrm{dd}, 2 \mathrm{H}, \mathrm{H}-4\right.$ and $\mathrm{H}-4^{\prime}, \mathrm{Ar}, J_{3,4}=J_{3^{\prime}, 4^{\prime}}=9.0 \mathrm{~Hz}, J_{4,6}=$ $\left.J_{4^{\prime}, 6^{\prime}}=2.6 \mathrm{~Hz}\right) ; 8.52(\mathrm{~d}, 2 \mathrm{H}, \mathrm{H}-6$ and H-6', Ar, $J=2.6 \mathrm{~Hz}) ; 9.31$ (bs, $\left.2 \mathrm{H}, \mathrm{NH}\right) .{ }^{13} \mathrm{C} \mathrm{NMR}$ (DMSO-D6): $38.50\left(2 \mathrm{CH}_{2} \mathrm{NH}\right) ; 115.86$ (C-1 and C-1', Ar); 118.70 (C-3 and C-3', Ar); 122.26, $125.45,126.18(6 \mathrm{CH}$ from $2 \mathrm{PhN}=\mathrm{N}) ; 125.45(\mathrm{C}-4, \mathrm{Ar}) ; 129.50$ (C-6, Ar); 131.00; 144.44; 152.00; 163.22; $168.84(2 \mathrm{C}=\mathrm{O})$. MS: $m / z, 507[\mathrm{M}-\mathrm{H}]^{+}(100) ; 283\left[\mathrm{M}-\mathrm{H}-\mathrm{C}_{13} \mathrm{H}_{8} \mathrm{~N}_{2} \mathrm{O}_{2}\right]^{+}(68) ; 240$ [M-H-C $\left.{ }_{15} \mathrm{H}_{13} \mathrm{~N}_{3} \mathrm{O}_{2}\right]^{+}$(7). Anal. Calcd for $\mathrm{C}_{28} \mathrm{H}_{24} \mathrm{~N}_{6} \mathrm{O}_{4}$ : C, 66.13; H, 4.76. Found: C, 66.59; $\mathrm{H}$, 5.09 .

\section{Biological methods}

\section{Antioxidant activity: free radical scavenging activity}

Free radical scavenging activity of tested compounds was evaluated by measuring their ability to neutralize 2,2-diphenyl-1-picrylhydrazyl (DPPH) and $\mathrm{OH}$ radicals.

DPPH assay. The DPPH-assay was performed as described before. ${ }^{32}$ The different aliquots $(0.1$ - $2 \mathrm{~mL}$ ) of $0.01 \mathrm{M}$ sample solution in methanol were added to $1 \mathrm{~mL}$ of $90 \mu \mathrm{M} \mathrm{DPPH} \mathrm{DH}^{\bullet}$ methanol (Sigma; St. Louis, MO) and filled up with $95 \%(\mathrm{v} / \mathrm{v})$ methanol to a final volume of 4 $\mathrm{mL}$. The same reaction mixture without tested compound was used as the control. Absorbances of the reaction mixtures and control were recorded at $515 \mathrm{~nm}$ after $1 \mathrm{~h}$. Commercial synthetic antioxidants, 3,5-di-tert-butyl-4-hydroxytoluene (BHT) (Aldrich; Taufkirchen, Germany) and 3tert-butyl-4-hydroxyanisole (BHA) (Fluka; Taufkirchen, Germany) were used as positive controls. For each sample, three replicates were recorded.

DPPH scavenging activity was expressed as radical scavenging activity (DPPH RSC). The percentage of DPPH RSC was calculated using the following equation: 
$\operatorname{RSC}(\%)=\left(A_{\text {blank }}-A_{\text {sample }} / A_{\text {blank }}\right) \times 100$.

$\mathrm{IC}_{50}$ values (the concentration of the tested compound in the reaction mixture which causes $50 \%$ of RSC) were determined by linear regression analysis from the obtained RSC values.

Hydroxyl-radical scavenging assay. Hydroxyl-radicals scavenging capacity $\left(\mathrm{HO}{ }^{\bullet} \mathrm{RSC}\right.$ ) of the tested compounds was evaluated by measuring the degradation of 2-deoxy-D-ribose (Aldrich; Taufkirchen, Germany) in the reaction with $\mathrm{OH}$ radicals, generated in situ in Fenton's reaction. ${ }^{32}$ These radicals attack the sugar 2-deoxy-D-ribose and degrade it into a series of fragments, some or all of which react on heating with 2-thiobarbituric acid (TBA) (Sigma; St. Louis, MO) at low $\mathrm{pH}$ to give a pink chromogen, which can be determined spectrophotometrically at $532 \mathrm{~nm}$. Different aliquots $(0.005-0.5 \mathrm{~mL})$ of sample solution in methanol were added to test tubes (final concentration ranged from 0.01 to $8 \mathrm{mM}$ ), each containing $0.1 \mathrm{~mL}$ of $5 \mathrm{mM} \mathrm{H}_{2} \mathrm{O}_{2}, 0.1 \mathrm{~mL}$ of 10 $\mathrm{mM} \mathrm{FeSO}_{4}$ and $0.1 \mathrm{~mL}$ of $0.05 \mathrm{M}$ 2-deoxy-D-ribose and $0.067 \mathrm{M} \mathrm{KH}_{2} \mathrm{PO}_{4}-\mathrm{K}_{2} \mathrm{HPO}_{4}$ buffer $\mathrm{pH}$ 7.4 to a final volume of $3 \mathrm{~mL}$. The same reaction mixture without sample was used as the control. After an incubation period of $1 \mathrm{~h}$ at $37{ }^{\circ} \mathrm{C}, 2 \mathrm{~mL}$ of TBA reagent $(10.4 \mathrm{~mL}$ of $60 \%$ (v/v) $\mathrm{HClO}_{4}, 3 \mathrm{~g}$ TBA and $120 \mathrm{~g}$ of trichloroacetic acid (Sigma; St. Louis, MO)) and $0.2 \mathrm{~mL}$ of $0.1 \mathrm{M}$ EDTA (Sigma; St. Louis, MO) were added to the reaction mixture, and the tubes were heated at $100{ }^{\circ} \mathrm{C}$ for $20 \mathrm{~min}$. After cooling, absorbance of the reaction mixtures and control were recorded at $532 \mathrm{~nm}$.

Percentage of $\mathrm{HO}^{\bullet} \mathrm{RSC}$ was calculated using the following equation:

$\operatorname{RSC}(\%)=\left(A_{\text {blank }}-A_{\text {sample }} / A_{\text {blank }}\right) \times 100$.

Three replicates were recorded for each sample; BHT and BHA were used as reference compounds.

Determination of lipid peroxidation (LP). The extent of LP was determined by measuring the absorbance of adduct produced in the reaction between TBA and malondialdehyde (MDA) as an oxidation product in the peroxidation of phospholipids from liposomes, by the TBA assay. ${ }^{32}$

The commercial preparation of liposomes "PRO-LIPO S" (Lucas-Meyer, Hamburg, Germany), $\mathrm{pH}$ 5-7, was used as a model system of biological membranes. The liposomes, 225-250 nm in diameter, were obtained by dispersing the commercial preparation in demineralized water (1:10) in an ultrasonic bath.

In the $\mathrm{Fe}^{2+}$ /ascorbate-induced lipids peroxidation, a $60 \mu \mathrm{L}$ suspension of liposomes was incubated with $20 \mu \mathrm{L}$ of $0.01 \mathrm{M} \mathrm{FeSO}_{4}, 20 \mu \mathrm{L}$ of $0.01 \mathrm{M}$ ascorbic acid, and $10 \mu \mathrm{L}$ of tested compound and filled with $0.05 \mathrm{M} \mathrm{KH}_{2} \mathrm{PO}_{4}-\mathrm{K}_{2} \mathrm{HPO}_{4}$ buffer, $\mathrm{pH} 7.4$ to a final volume of $3 \mathrm{~mL}$. Samples were incubated at $37^{\circ} \mathrm{C}$ for $1 \mathrm{~h}$, and LP was terminated by adding $2 \mathrm{~mL}$ of TBA reagent and $0.2 \mathrm{~mL}$ of EDTA, and heating the test tubes at $100{ }^{\circ} \mathrm{C}$ for $20 \mathrm{~min}$. After centrifugation (4000 $\mathrm{rpm}$ for $10 \mathrm{~min}$ ), the content of the MDA (TBARS) was determined by measuring the absorbance of the product at $532 \mathrm{~nm}$.

Analyses were compared with the commercial synthetic antioxidants BHT and BHA as a positive control. All reactions were carried out in triplicate.

The percentage of LP inhibition was calculated by the following equation: $I(\%)=\left(A_{0}-A_{1}\right) / A_{0} \times 100$ 
where $A_{0}$ was the absorbance of the control (without the test compound) and $A_{1}$ was the absorbance in the presence of the inhibitor.

\section{Antiproliferative activity}

Cell lines. Six human tumor cell lines and one human non-tumor cell line were used in the study: human breast adenocarcinoma ER+, MCF7, human breast adenocarcinoma ER-, MDA-MB-231, prostate cancer PC3, cervix epithelioid carcinoma, HeLa S3, human melanoma, Hs 294T, chronic myelogenous leukemia, K562, and normal fetal lung fibroblasts, MRC-5.

The cells were grown in Dulbecco's modified Eagle's medium (DMEM) with 4.5\% of glucose (MCF7, MDA-MB-231, PC3, HeLa S3, Hs 294T and MRC-5) or in RPMI 1640 (K562). Media were supplemented with $10 \%$ of fetal calf serum (FCS, NIVNS) and antibiotics: $100 \mathrm{IU} / \mathrm{mL}$ of penicillin and $100 \mu \mathrm{g} / \mathrm{mL}$ of streptomycin (ICN Galenika). All cell lines were cultured in flasks $\left(\right.$ Costar, $25 \mathrm{~cm}^{2}$ ) at $37{ }^{\circ} \mathrm{C}$ in the $100 \%$ humidity atmosphere and $5 \%$ of $\mathrm{CO}_{2}$. Only viable cells were used in the assay. Viability was determined by dye exclusion assay with trypan blue.

SRB assay. Cytotoxicity was evaluated by colorimetric sulforhodamine B (SRB) assay. ${ }^{33}$ Briefly, single cell suspension was plated into 96-well microtiter plates (Costar, flat bottom): $5 \times$ $10^{3}$ cells (MCF7, MDA-MB-231, PC3, HeLa S3, Hs 294T and MRC-5) or $10^{4}$ (K562) cells per $180 \mathrm{~mL}$ of medium. Plates were pre-incubated $24 \mathrm{~h}$ at $37{ }^{\circ} \mathrm{C}, 5 \% \mathrm{CO}_{2}$. Tested substances at concentrations ranging from $10^{-8}$ to $10^{-4} \mathrm{M}$ were added to all wells except for the control ones. After incubation period $\left(48 \mathrm{~h} / 37{ }^{\circ} \mathrm{C} / 5 \% \mathrm{CO}_{2}\right) \mathrm{SRB}$ assay was carried out as follows: $50 \mu \mathrm{L}$ of $80 \%$ trichloroacetic acid was added to all wells; an hour later the plates were washed with distilled water, and $75 \mu \mathrm{L}$ of $0.4 \%$ SRB was added to all wells; half an hour later the plates were washed with citric acid (1\%) and dried at room temperature. Finally, $200 \mu \mathrm{L}$ of $10 \mathrm{mmol}$ Tris ( $\mathrm{pH}$ 10.5) was added to all wells. Absorbance $(A)$ was measured on the microplate reader (Multiscan MCC340, Labsystems) at 540/690 nm. The wells without cells, containing complete medium only, served as the blank.

Cytotoxicity was calculated according to the formula:

CI $(\%)=\left(1-A_{\text {sample }} / A_{\text {control }}\right) \times 100$.

Data analysis. Two independent experiments were set out in quadruplicate for each concentration of the compound. $\mathrm{IC}_{50}$ value defines the dose of compound that inhibits cell growth by $50 \%$. The $\mathrm{IC}_{50}$ of compounds was determined by Median effect analysis.

\section{Crystal structure determination}

A single crystal of compound $\mathbf{3}$ was mounted on a glass fiber and measured on an Oxford Diffraction Gemini S system. The diffraction data for compound $\mathbf{3}$ were collected at the temperature of $200 \mathrm{~K}$ with graphite-monochromated MoK $\alpha$ radiation $(\lambda=0.7107 \AA)$. The data reduction was performed with the program package CrysAlis RED. ${ }^{35}$ The space group determination was based on an analysis of the Laue class and the systematically absent reflections. The structure of compound $\mathbf{3}$ was solved by direct methods using SIR92 ${ }^{36}$ and refined using full-matrix least-squares. Non-hydrogen atoms were refined anisotropically; the $\mathrm{C}-\mathrm{H}$ hydrogen atoms were included at calculated positions riding on their attached atoms with fixed distances of $0.93(\mathrm{CH})$ or $0.97 \AA\left(\mathrm{CH}_{2}\right)$ and all $\mathrm{O}-\mathrm{H}$ hydrogen atoms were identified on 
difference electron density maps and isotropically refined. The data were subjected to the removal of the scattering contribution from heavily disordered solvent molecules, which must be $n$-hexane molecules, using the Squeeze routine as implemented in the program PLATON. ${ }^{37}$ All calculations were performed using SHELXL97, ${ }^{38}$ PARST ${ }^{39}$ and PLATON, ${ }^{37}$ as implemented in the WINGX ${ }^{40}$ system of programs. The crystal data and refinement parameters are summarized in Table 7.

Table 7. The crystal data and refinement parameters

\begin{tabular}{|c|c|}
\hline \multicolumn{2}{|r|}{ Crystal data } \\
\hline Chemical formula & $\mathrm{C}_{18} \mathrm{H}_{17} \mathrm{NO}_{6}$ \\
\hline$M_{\mathrm{r}}$ & 343.33 \\
\hline Crystal system, space group & Tetragonal, $I 4_{1} c d$ \\
\hline Temperature $(\mathrm{K})$ & 200 \\
\hline$a, c(\AA)$ & $33.3098(12), 6.9315(4)$ \\
\hline$V\left(\AA^{3}\right)$ & $7690.8(6)$ \\
\hline Z & 16 \\
\hline$F(000)$ & 2880 \\
\hline Radiation type & Mo $K \alpha$ \\
\hline$\mu\left(\mathrm{mm}^{-1}\right)$ & 0.09 \\
\hline Crystal shape & Prism \\
\hline Colour & Colorless \\
\hline Crystal size (mm) & $0.60 \times 0.18 \times 0.15$ \\
\hline \multicolumn{2}{|r|}{ Data collection } \\
\hline Absorption correction & Multi-scan \\
\hline & $\begin{array}{l}\text { CrysAlis RED, Oxford Diffraction Ltd., Version 1.171.32.24 } \\
\text { Empirical absorption correction using spherical harmonics, } \\
\text { implemented in SCALE3 ABSPACK scaling algorithm. }\end{array}$ \\
\hline$T_{\min }, T_{\max }$ & $0.866,1.000$ \\
\hline $\begin{array}{l}\text { No. of measured, } \\
\text { independent and observed }[I \\
>2 \sigma(I)] \text { reflections }\end{array}$ & $11071,4156,2961$ \\
\hline$R_{\text {int }}$ & 0.028 \\
\hline$\theta$ values $\left(^{\circ}\right)$ & $\theta_{\max }=29.3, \theta_{\min }=3.2$ \\
\hline \multirow[t]{2}{*}{$\begin{array}{l}\text { No. and frequency of } \\
\text { standard reflections }\end{array}$} & $h=-45 \rightarrow 25, k=-42 \rightarrow 29, l=-8 \rightarrow 8$ every 60 min \\
\hline & Refinement \\
\hline Refinement on & $F^{2}$ \\
\hline$R\left[F^{2}>2 \sigma\left(F^{2}\right)\right], w R\left(F^{2}\right), S$ & $0.049,0.107,1.02$ \\
\hline No. of reflections & 4156 \\
\hline No. of parameters & 238 \\
\hline
\end{tabular}


No. of restraints

$\mathrm{H}$-atom treatment

1

$\mathrm{H}$ atoms treated by a mixture of independent and constrained

refinement

$\Delta \rho_{\max }, \Delta \rho_{\min }\left(\mathrm{e} \AA^{-3}\right)$

$0.23,-0.20$

\section{Acknowledgements}

Authors would like to thank the Ministry of Science and Technological Development of the Republic of Serbia for financial support (Grant No. 142052).

\section{References}

1. Valko, M.; Izakovic, M.; Mazur, M.; Rhodes, Ch. J.; Telser J. Mol. Cell. Biochem. 2004, $266,37$.

2. (a) Dröge, W. Physiol. Rev. 2002, 82, 47. (b) Valko, M.; Rhodes, C. J.; Moncol, J.; Izakovic, M.; Mazur, M. Chem.-Biol. Interact. 2006, 160, 1. (c) Valko, M.; Leibfritz, D.; Moncol, J.; Cronin, M. T. D.; Mazur, M.; Telser, J. Int. J. Biochem. Cell Biol. 2007, 39, 44. (d) Soler, C.; Espin, J.C.; Wichers, H. Phytochem. Anal. 2000, 11, 1.

3. Al-Dabbas, M. M.; Suganuma, T.; Kitahara, K.; Hou, D. X.; Fujii, M. J. Ethnopharmacol. 2006, 108, 287.

4. Ljubincic, P.; Azaizeh, H.; Portnaya, I.; Cogan, U.; Said, O.; Abu Saleh, K.; Bomzon, A. J. Ethnopharmacol. 2005, 99, 43.

5. Fujisawa, S.; Atsumi, T.; Kadoma, Y.; Sakagami, H. Toxicology 2002, 177, 39.

6. Sestili, P.; Diamantini, G.; Bedini, A.; Cerioni, L.; Tommasini, I.; Tarzia, G.; Cantoni, O. Biochem. J. 2002, 364, 121.

7. Grosser, N.; Schröder, H. Arterioscler. Thromb. Vasc. Biol. 2003, 23, 1345.

8. Soltermann, A. T. ; de la Peña, D.; Nonell, S.; Amat-Guerri, F.; García, N. A. Polym. Deg. Stab. 1995, 49, 371.

9. Fujimori, T. ; Yamada, S.; Yasui, H.; Sakurai, H.; Tu, Y.; Ishida, T. J. Biol. Inorg. Chem. 2005, 10, 831 .

10. Rotem, R.; Tzivony, Y.; Flescher, E. Prostate 2000, 42, 172.

11. Logrado, L. P. L. ; Silveira, D.; Romeiro, L. A. S.; de Moraes, M. O.; Cavalcanti, B. C.; Costa-Lotufo, L. V.; do Ó Pessoa, C.; dos Santos, M. L. J. Braz. Chem. Soc. 2005, 16, 1217.

12. Erickson, K. L.; Beutler, J. A.; Cardellina II, J. H.; Boyd, M. R. J. Org. Chem. 1997, 62, 8188 .

13. (a) Ott, I. ; Schmidt, K.; Kircher, B.; Schumacher, P.; Wiglenda, T.; Gust, R. J. Med. Chem. 2005, 48, 622. (b) Marzotto, A.; Clemente, D. A.; Gerols, T.; Valle, G. Polyhedron 2001, 
20, 1079. (c) Etcheverry, S. B.; Williams, P. A. M.; Barrio, D. A.; Sálice, V. C.; Ferrer, E. G.; Cortizo, A. M. J. Inorg. Biochem. 2000, 80, 169.

14. Singh, N. K.; Singh, N.; Prasad, G. C.; Sodhi, A.; Shrivastava, A. Bioorg. Med. Chem. 1997, $5,245$.

15. Bandgar, B. P.; Pandit, S. S. Tetrahedron Lett. 2003, 44, 2331.

16. (a) Cwik, A.; Hell, Z.; Hegedüs, A.; Finta, Z.; Horváth, Z. Tetrahedron Lett. 2002, 43, 3985. (b) Vorbrüggen, H.; Krolikiewicz, K. Tetrahedron 1993, 49, 9353. (c) Kamata, K.; Agata, I. J. Org. Chem. 1998, 63, 3113. (d) Jnaneshwara, G. K.; Deshpande, V. H., Lalithambika, M.; Ravindranathan, T.; Bedekar, A.V. Tetrahedron Lett. 1998, 39, 459. (e) Clarke, D. S.; Wood, R. Synth. Commun. 1996, 26, 1335. (f) Bolm, C.; Weickhardt, K.; Zehnder, M.; Ranff, T. Chem. Ber. 1991, 124, 1173. (g) Oussaid, B.; Berlan, J.; Soufiaoui, M.; Garrigues, B. Synth. Commun. 1995, 25, 659. (h) Katritzky, A. R.; Cai, C.; Suzuki, K.; Singh, S. K. J. Org. Chem. 2004, 69, 811. (i) Fukuhara, T.; Hasegawa, C.; Hara, S. Synthesis 2007, 1528. (j) Schwekendiek, K.; Glorius, F. Synthesis 2006, 2996.

17. Crogsinani, S.; Young, A. C.; Linclau, B. Tetrahedron Lett. 2004, 45, 9611.

18. Fan, L.; Lobkovsky, E.; Ganem, B. Org. Lett. 2007, 9, 2015.

19. Nigović, B.; Komorsky-Lovrić, Š.; Šimunić, B. Electroanal. 2005, 17, 839.

20. Przybylski, P.; Huczynski, A.; Pyta, K.; Brzezinski, B.; Barth, F. Curr. Org. Chem. 2009, $13,124$.

21. Wiggins, L. F.; Beard, C. C.; James, J. W. British Patent 953 427, 1964; Chem. Abstr. 1964, $60,15875$.

22. Clarke, D. S.; Wood, R., Synthetic Communications 1996, 26, 1335.

23. Bao, K.; Zhang, W.; Zhang, C.; Qu, Y.; Tian, L.; Wu, L.; Zhao, X.; Cheng, M. Molecules 2007, 12, 2123.

24. Limousin, C.; Cleophax, J.; Loupy, A.; Petit, A. Tetrahedron 1998, 54, 13567.

25. Djurendić, E. A.; Vastag, Gy. Gy.; Surányi, T. M.; Popsavin, M. M.; Penov-Gaši, K. M. J. Serb. Chem. Soc. 2000, 65, 681.

26. Zhou, P.; Natale, N. R. Synthetic Communications 1998, 28, 3317.

27. Bayer and Co., D. R. P. 164128; C.1905 II,1476; B.10.81, I 38, II, 53

28. Miljković, D. A.; Djurendić, E. A.; Šuranji, T. M. Review of Research, Faculty of SciencesUniversity of Novi Sad, 1983, 13, 5.

29. Djurendić, E. A.; Surányi, T. M.; Miljković, D. A. Coll. Czech. Chem. Comm. 1991, 56, 1446.

30. Djurendić, E. A.; Surányi, T. M.; Miljković, D. A. Coll. Czech. Chem. Comm. 1990, 55, 1763.

31. Farrugia, L. J. J. Appl. Cryst. 1997, 30, 565.

32. Mimica-Dukić, N.; Božin, B.; Sokolović, M.; Simin, N. J. Agric. Food Chem. 2004, 52, 2485.

33. Skehan, P.; Storeng, R.; Scudiero, D.; Monks, A.; McMahon, J.; Vistica, D.; Warren, T. J.; Bokesch, H.; Kenney, S.; Boyd, R. M.; J. Natl. Cancer Inst. 1990, 82, 1107. 
34. Vogel's Textbook of Practical Organic Chemistry, 5th Ed., Longman Group Limited, London, 1989, pp. 920-921.

35. Oxford Diffraction CrysAlis CCD and CrysAlis RED. Versions 1.171., Oxford Diffraction Ltd, Abingdon, Oxfordshire, England, 2008.

36. Altomare, A.; Cascarano, G.; Giacovazzo, C.; Guagliardi, A. J. Appl. Cryst. 1993, $26,343$.

37. Sheldrick, G. M.; SHELX97, Programs for Crystal Structure Analysis, University of Göttingen, Germany, 1997.

38. Nardelli, M. J. J. Appl. Cryst. 1995, 28, 659.

39. Spek, A. L.; PLATON, A Multipurpose Crystallographic Tool, University of Utrecht, The Netherlands, 1998.

40. Farrugia, L. J. J. Appl. Cryst. 1999, 32, 876. 